\title{
Analysis of Investors Herding Behavior: An Empirical Study from Istanbul Stock Exchange
}

\author{
Ali Mohammed Adem and Serra Eren Sarioğlu
}

\begin{abstract}
This study investigates the existence of herding behavior in Istanbul Stock Exchange using a narrow index for the period between January 1, 2000 and December 31, 2018. Besides, the study tests herding behavior of investors during high and low volatility periods. The data is collected from Finnet and it contains daily, weekly and monthly return data. The study uses both modified CSSD and CSAD models. The finding of the study shows that herding is more prevalent when the market falls and from the three data type it is more prevalent in the daily data. This indicates that investors behave rationally when the market rises and they become irrational and herd the market consensus when the market falls. On the other hand, the level of herding is significantly high during high market volatility periods. Therefore, we conclude that there is an asymmetrical investor behavior while pricing assets in Istanbul Stock Exchange.
\end{abstract}

Index Terms - asymmetrical herding, herding behavior, negativity bias.

\section{INTRODUCTION}

Since 1990s besides investigating herding behavior of investors in both emerging and developed countries financial markets, researchers' main interest was to examine the behavior of investors during market volatility periods or during financial crisis periods [1], [2], [3], [4], [5], [6], [7], [8], [9], [10], [11], [12], [13], [14], [15], [16]. According to [9], during financial crisis periods obtaining additional reliable information is costly and imitating the action of other investor(s) is considered as a better solution to solve this problem. So the tendency of herd behavior may be strong during high market stress periods.

In financial markets information changes frequently and the volume of information is also significantly high. Furthermore, the level of investors' sophistication is different from one investor to another. As a result, investors may not fully analyze the information they receive and they may prefer to imitate the action of other investor(s). Thus, during high uncertainty periods some investors may mimic the action of others. This behavior of investors to imitate the actions of other investors is called herding [3]. Imitation of other investors' action occurs through observation of their actions (decisions) on a particular assets and it is followed by moving in line with the aggregate market activity. Herding behavior which is formed in this way leads to a major shift into and out of the same assets. The main implication of herding is that investors tend to rely on the consensus opinion and past trades pattern than analyzing and interpreting news as well as prediction of fundamental asset pricing frameworks
[17]. Herding has important implications for financial markets because in the process investors ignore their own analysis and try to imitate the action of other investors. The end result of herding is that important information may not be reflected in the price of securities and in the process, the price of securities may move away from their fundamental values. Thus, herding may lead investors to shift into or out of the same securities and may lead to the formation of bubble [3]. Since investors seek the comfort of market consensus, the level of herding may be strong during high market stress periods. During market stress periods investors want to achieve, at a minimum, the average market returns by following the herd. Furthermore, obtaining additional reliable information is perceived to be costly during market stress periods and following the herd is considered as a better solution to this problem [3], [9].

When market volatility increases, investors are under strong pressure and prone to errors and the emotion to herd becomes particularly strong during high market volatility periods. Under such conditions, investors are not concerned about the reasonable price of securities and they hope only to be relieved from the strong pressure. If investors herd out of emotion, herding behavior would markedly intensify during periods of great market pressure [9].

According to [1], during periods of unusual market movements individuals are most likely to suppress their own beliefs in favor of the market consensus and most likely herd behavior would emerge during the market stress periods. Reference [1] believe that individuals are more likely to imitate the market consensus during periods of unusual market movements. Thus, herd behavior would most likely emerge during market stress periods. Reference [18] investigated herding behavior in Portuguese financial market for the period between January 1998 and December 2005. Their finding shows that herding exists in the Portuguese market and it takes place more during periods where market returns are low or when the market declines. On the other hand, [19] find that analysts are more likely to herd to a consensus forecast when there is little uncertainty in earnings. So the finding of [19] shows that herding may be prevalent during low market volatility periods. In addition, Hwang \& Salmon (2004) found herding when the market is quiet and investors are confident of the direction in which markets are heading.

However, investors' reaction to information during market stress period is not symmetrical when the market rises and 
falls. According to [2], the tendency of herding in the down market is higher that the tendency of herding when the market rises. This shows that investors' reaction to news is asymmetrical and herding behavior is also asymmetrical in the up and down market conditions. The above theoretical and empirical finding shows that herding behavior is more prevalent when the market volatility is high [1], [3], [9], [18] and according to [19], [5] and [4] herding occurs during low market volatility periods.

To the best of our knowledge there is no study which investigates herding behavior of investors when the market volatility level is high as well as low in Istanbul stock exchange. Thus, this empirical study investigates herding behavior of investors when Istanbul stock exchange is in low and high volatility during the period between January 1, 2000 and December 31,2018. We hypothesis that when the market performance is good, investors' confidence will increase and they will make an independent decision. On the other hand, when the market's performance is negative, investors' confidence will be eroded and they try to imitate the market consensus to achieve the average market return.

We arranged the remaining part of this paper as follows. Section two discusses about literature reviews. Section three deals with data and research methodology. The last two sections focuses on empirical analysis and conclusions respectively.

\section{LITERATURE REVIEWS}

The word herding or herding behavior refers to the process where economic agents are imitating each other's action(s) and/or base their decisions upon the action(s) of others. However, different researchers define the term herding with different expressions. Reference [20] define herding as a correlated trading across investors. Reference [21] define the term herding as behavioral patterns that are correlated across individuals (investors). Reference [22] define herding as excessive agreement among analysts prediction; [23] define herding as a group of investors trading in the same direction over some period of time. Reference [24] define it as a mutual imitation. Reference [25] define herding as a correlation in the positions taken by different managers. Reference [4] define herding as a form of correlated behavior or the suppression of private information and imitation without reference to fundamentals; [26] define herding as a behavior of investors in a group following each other into and/or out of the same securities over some period of time. In general, herding requires a coordination mechanism.

Basically, there are two types of herding: spurious and intentional herding. Spurious herding occurs when a group of investors faces similar decision problems and/or similar information sets, and arrive to similar decision. It is supposed that such herding behavior brings financial markets to efficiency because spurious herding arises from fundamentally driven factors. On the other hand, intentional herding results from a clear intent by a market participant to imitate the actions of other investors. Intentional herding need not bring efficiency. Rather, it can lead to excessive volatility and systemic risk [25].

Intentional herding can be divided in to two: rational and non-rational herding. The non-rational herding centers on investor psychology and holds that investors following one another blindly and foregoing rational analysis [21]. The basic cause of non-rational herd behavior are psychological stimuli and restraints, such as pressure from social circles and/or social conventions [27].

The rational herding's view focus on externalities, i.e., information difficulties or incentive issues [21]. The rational herding can be caused by the principal agent relationships. For example a manager may imitate the actions of other managers, by completely ignoring private information, in order to avoid being revealed low performer. However, the intermediate view holds that decision makers are near rational, economizing on information processing or information acquisition costs by using heuristics. The incentive to follow the herd increases the size of the herd, and if enough investors follow the herd, each additional investor action will become purely based on others' actions [21]. There are three empirically proven potential reasons for rational herd behavior in financial markets. These are imperfect information, concern for reputation and compensation structures [25].

\section{A. Heuristics}

Individuals thinking process does not work like a computer. Instead, the human brain often processes information using shortcuts and emotional filters. These processes influence financial decision makers such that people often act in a seemingly irrational manner, routinely violate traditional concepts of risk aversion, and make predictable errors in their forecasts [28]. One of the criticism for the classical economics and finance is to their assumption that a decision maker would consider all relevant information and come up with the best choice. However, we need to ask one question here. How does people make decisions with limited time and information in a world of uncertainty? Since too much information is difficult to deal with, people have developed shortcuts or heuristics in order to come up with reasonable decisions [29]. Many decisions are based on beliefs concerning the likelihood of uncertain events [30]. However, heuristics may lead to biases [29].

According to [29], heuristic is a decision rule that utilizes a subset of information set. Due to the impossibility of analyzing all information and for economizing decision, people use heuristics without even realizing it. Heuristics are shortcuts that simplify the complex methods of assessing the probabilities and values necessarily required to make a decision. Heuristics eliminate the need for extensive calculation to solve a problem. Since heuristics are used as a shortcut to simplify complex situation, it become a device for simplifying the process of choosing between alternatives. The following are the rationale for using heuristics. First, decision makers may not have the ability and knowledge to solve a problem, or the decision maker may not have the resources needed to get a solution, and the resources including the methods may be time taking as well as costly to solve a problem. Second, a decision maker may be unable to obtain all the information necessary for attaining an optimal solution or may not be able to do so by the time a decision must be made. Third, the use of heuristics may be the only plausible method at the time of uncertainty [31]. Thus, herding is a type of heuristic that investors use to solve a decision problem. 
Heuristics are important but they lead to severe and systematic errors. There are three types of heuristics: representativeness, availability, and anchoring and adjustment [30]. Representativeness includes judgments of the likelihood of an event based on its similarity to a class of events or individuals. The use of representativeness heuristic sometimes reflects a failure to take into account relevant information before judgment is made. Availability heuristic indicats the weight given to information in place of probability or frequency. The weighting is attributable to the ease of recall and the content of what is recalled. Availability may be due to some recent dramatic news event. The base of availability heuristic can be experience, memory and imagination. Anchoring and adjustment is a type of heuristic that involves adjustment from some starting point. The starting point most of the time refers to recent data [31]. Anchoring is the tendency to change one's view more slowly than is appropriate [29].

Besides heuristics, there is another tendency of human beings which is called negativity bias and in this case humans give more emphasis to negative events or news.

\section{B. Negativity bias}

Negativity bias, is available in most situations, refers that negative events are more important, powerful and dominant than positive events. Negative events are more powerful with respect to their objective magnitude than positive events. According to this view, humans give greater weights to negative events than positive events [32]. Negativity bias refers to the relative strength of negative events over positive events [33].

Negative events like losing money, being abandoned by friends and receiving criticism have a greater impact on the individual than positive events like winning money, gaining friends and receiving praise. In the presentation of equal measure of good and bad, have asymmetric effect, the psychological effect of bad events overweight the good ones. The contribution of negative information towards a final impression or opinion is stronger than positive information. At the same time, bad events wear off more slowly than good events and bad events has longer lasting effects. Moreover, single bad events are far stronger than even the strongest good ones and single negative event can probably undo the benefits of many positive interactions. Researchers explained that people react more strongly to bad events than good events. Bad events are so much stronger than good ones that the good must outnumber the bad in order to prevail [34].

Negative emotions are more powerful and important than positive emotions. The human brain responds more strongly to bad things than good things. Empirical evidence shows that high motivation and pragmatic concerns cause people to process relevant information more thoroughly. However, human cannot afford to process all information symmetrically, so they must prioritize their cognitive resources and focus on what is important. If bad is generally stronger than good, then information involving bad events should receive more thorough processing than information about good events. Greater information processing may be reflected in paying more attention to bad events. People are engaged in more thinking and reasoning about bad than good events. In other words, people devote more cognitive energy to thinking about bad things than thinking about good things. For this reason, bad information has more power than good information for attracting in an automatic and unintentional fashion. Journalists and communication scientists argued that bad events are more newsworthy, attract more reader attention and bad news also cause to sell more papers. Therefore, bad information does receive more thorough information processing than good information. Bad information is more likely to seize attention and it receives more conscious processing as well [34].

Since bad is stronger than good, bad reputations are easy to acquire but difficult to lose, whereas good reputations are difficult to acquire but easy to lose. This finding shows that once unfavorable characteristics are acquired, it is so difficult to remove the effect because a large number of good things or events are necessary for their disconfirmation [34]. This finding is consistent with the situation observed in financial markets. For example, the 2007/08 financial crisis occurs within a short period of time but to get out of the financial crisis, it was necessary to wait almost one decade for United States of America and it was mandatory take more positive measures. In line with the finding of [34], the good economic conditions before the crisis lost easily during the crisis period and it necessitates taking more positive economic measures to stimulate and reinstate the economy to the previous position.

The greater power of bad than good information is also observed in the speed of decision-making and the amount of information sought. Generally, people made faster decisions with less information when they were given negative information than positive information. The prospect theory of [35] shows that losses have more impact than comparably size gains in economic decision-making. This is equivalent to the saying: bad is stronger than good. Negative emotions and bad moods have stronger impacts than good ones on information processing. The greater impact of bad than good is extremely pervasive. It is found in connection with decisions about the future, complex human information processing and emotional responses.

According to [36], negative information influence evaluations more strongly than a comparable positive information. Reference [37] empirically confirmed that negative events has a larger amplitude effect than positive events. An experiment made on news viewers' reaction to news content shows that negative news elicits stronger and more sustained reactions than does positive news. These suggests that people are more reactive and attentive to negative news than they are to positive news. Thus, there is asymmetry to news and news contents are dominated by negative events. News is predominantly negative because humans are more interested in and reactive to negative information. Humans have a reasonably well established tendency to react more strongly to negative than positive information [33].

Therefore, negativity bias is a good theory to explain investors' reaction to good and bad news as well as it may also be a good theory to explain investors' asymmetrical behavior during low and high market volatility periods. Negativity bias is also so relevant to explain why investors' behavior is asymmetrical in the up and down market. 


\section{DATA AND RESEARCH METHODOLOGY}

This section presents the source and types of data as well as the methodology employed to investigate the proposed objectives.

\section{A. Data}

This study first test the existence of herding behavior in Istanbul stock exchange and later on we tested herding behavior for sub periods. In order to test the existence of herding towards the market consensus in Istanbul Stock Exchange daily, weekly and monthly stock price data are taken from January 1, 2000 to December 31, 2018. Daily, weekly as well as monthly closing stock prices and closing index prices are used to calculate their respective return amount in the study period. BIST 30 and BIST100 index are used as a market indicator for this study and their closing prices are used to calculate returns. All the data is collected from Finnet analiz excel model.

\section{B. Research Methodology}

In behavioral finance literatures, there are three different methods to test herding behavior of investors. The first method, Lakonishok, Shleifer and Vishny (LSV) model, focus on the direction of investors decision or it focuses on the percentage of investors who buy an asset while the other investors sells those assets and vice versa. The second method measures herding based on cross sectional stock's return data. Thus, cross sectional dispersion of stock returns (CSSD) model and cross sectional absolute deviation (CSAD) of stock returns model are the models which use stock return data to test the existence of herding behavior. The third method uses the volatility of beta coefficient to test herding behavior. This study uses models that uses stock return data to test herding behavior.

\section{Cross sectional dispersion of stock returns model}

To measure the existence of herding using stock returns [1] developed a cross sectional standard deviation of stock returns model. According to [1], the standard deviation is expected to be low when individuals herd around market consensus. In essence, dispersion quantify the average proximity of individual stock returns to the mean of the market return. The lower limit of a dispersion is zero that indicates a perfect unison with the market. On the other hand, as individual returns begin to vary from the market return, the level of dispersion increases. According to [1], individuals are most likely to suppress their own beliefs in favor of the market consensus during periods of unusual market movements and herd behavior would most likely emerge during market stress periods. The predictions concerning the behavior of dispersions during periods of market stress also comes from the rational asset pricing models. The rational asset pricing model relate the individual asset returns to one common factor i.e. market return. The rational asset-pricing model relates a large change in market returns to an increase in dispersion because individual assets differ in their sensitivity to the market return. In this way, [1] model and rational asset pricing models offer conflicting predictions for the behavior of dispersions during periods of market stress.

To measure the return dispersion, [1] proposed the crosssectional standard deviation (CSSD) method, which is expressed as:
$\operatorname{CSSD}_{\mathrm{t}}=\sqrt{\frac{\sum_{i=1}^{N}(R i, t-R m, t)^{2}}{(N-1)}}$

Where $\mathrm{N}$ is the number of firms in the portfolio, $\mathrm{Ri}, \mathrm{t}$ is the observed stock return of firm $i$ at time $t, R m, t$ is the market return at time t. This model suggests that if herding occurs, investors will make similar decisions, leading to lower return dispersions. But low dispersion by itself do not guarantee the presence of herding. According to [2], CSSD measure quantifies the average proximity of individual returns to the realized returns.

To test the existence of herding empirically, [1] used the following model.

$\mathrm{S}_{\mathrm{t}}=\alpha+\beta^{\mathrm{L}} \mathrm{D}^{\mathrm{L}}+\beta^{\mathrm{U}} \mathrm{D}^{\mathrm{U}}+\varepsilon \mathrm{t}$

Where $\mathrm{St}$ is the return dispersion at time t. DLt is a dummy variable at time $t$ taking on the value of one when the market return at time $\mathrm{t}$ lies in the extreme lower tail of the distribution, and zero otherwise. Similarly, DUt is a dummy variable with a value of one when the market return at time $t$ lies in the extreme upper tail of the distribution, and zero otherwise. The $\alpha$ coefficient denotes the average dispersion of the sample excluding the regions covered by the two dummy variables. The rational asset pricing models predict significantly positive coefficients for $\beta \mathrm{L}$ and $\beta \mathrm{U}$; and statistically significant and negative values for $\beta \mathrm{L}$ and $\beta \mathrm{U}$ would indicate the presence of herding.

According to [1], individuals herd to the market means that individuals suppress their own beliefs and their investment decisions; thereby only depends on the collective actions of the market, even when they disagree with its predictions. This way of herd formation implies that investors are attracted to the consensus of the market and it means that individual stock's return would not move from the market return. Reference [1] believe that individuals are more likely to imitate the market consensus during periods of unusual market movements. Thus, herd behavior would most likely emerge during market stress periods. A natural candidate for market stress periods are those trading intervals characterized by large price swings in average prices. In such periods, security returns will move along with the market returns. Market stress is defined as an abnormally large price movement. Since the definition of market stress is arbitrary [1] used the following criteria.

Reference [1] define market stress in an arbitrary ways using a 1 or 5 percent criteria. They used a 1 or 5 percent upper or lower tail of the market return distribution as a criterion to specify market stress period. However, this model ignores that the impact of investors' psychological factor is available throughout the investment decision process and herding does not only exist when a market is in a stress period. Many empirical findings revealed that during market stress period investors make decisions based on fundamentals rather than imitating an overall market consensus [1], [4], [10], [13]. In addition, [4] found herding when the market is quiet and investors are confident of the direction in which markets are heading. Therefore, it is important to study herding when the market return falls in the whole two half (negative and positive) of the return distribution.

All the previous researches investigated the existence of herding when the market return lies in $1 \%$ and $5 \%$ of the lower and upper region of the market return distribution [1], [2], [4], [6], [10], [12], [13], [14], [15]. Since the total area of 
the normal distribution equals to one ( 0.5 to the left and 0.5 to the right from the mean), the previous researches ignored to investigate herding in the major area of the market return distribution. That is, $1 \%$ and $5 \%$ is used as a cutoff point to specify the market stress period in the previous researches. In this case the remaining $0.49(49 \%)$ or $0.45(45 \%)$ of the market return distribution remain unexplained or did not investigated. Therefore, this study investigated the existence of herding in Istanbul Stock Exchange when the market return falls below the zero or lies above the zero. Using the same logic to [1], this study developed the following model and it is called modified CSSD model. Unlike [1] model that uses a dummy variables as an independent variables to investigate herding, the following model uses an actual or realized stock return data.

$$
\operatorname{CSSD}_{t}=\alpha+\beta^{n} R^{n}{ }_{t}+\beta^{p} R^{p_{t}}+\varepsilon t \ldots \ldots . . e q(3)
$$

Where, CSSDt is the Cross sectional standard deviation at time $t, \alpha$ refers a constant when the market return is zero, RMnt is a realized negative market return at time t, RMpt is a realized positive market return at time $t, \beta n$ is the coefficient of RMn, $\beta \mathrm{p}$ is the coefficient of RMp, and $\varepsilon t$ is the error term. A negative and statistically significant coefficient for the above regression equation shows the presence of herding towards the market consensus. To measure the return dispersion the usual cross-sectional standard deviation (CSSD) method is used.

Cross sectional absolute deviation (CSAD) of stock returns model

Reference [2] have extended the work of [1] to measure herding and developed the cross sectional absolute deviation of stock returns model. The new model is a nonlinear model that is used to examine the relation between the level of equity return dispersions and the overall market return. Reference [2] expect that in the presence of severe or moderate herding the return dispersion will decrease. The cross sectional absolute deviation model as a measure of return dispersion demonstrates rational asset pricing model predicts equity return dispersions are a linear and an increasing function of market returns. However, if investors follow (herd) the aggregate market behavior and ignore their own analysis during periods of large price movements, then the linear and increasing relation between dispersion and market return will no longer holds. In other words, the relation become nonlinearly increasing or even decreasing. Thus, the CSAD model is built on this premise. However, CSAD value by itself is not a measure of herding rather the relationship between CSAD and market return is used to detect herd behavior. Reference [2] developed the following regression equation to allow for the possibility that the degree of herding may be asymmetrical in the up and down market.

$\operatorname{CSAD}_{\mathrm{t}}^{\text {up }}=\alpha+\gamma_{1}{ }^{\text {up }}\left|\mathrm{R}_{\mathrm{m}, \mathrm{t}}{ }^{\text {up }}\right|+\gamma_{2}{ }^{\text {up }}\left(\mathrm{R}_{\mathrm{m}, \mathrm{t}^{\text {up }}}\right)^{2}+\varepsilon_{\mathrm{t}} \ldots$ eq(4) $\operatorname{CSAD}_{t}^{\text {down }}=\alpha+\gamma_{1}{ }^{\text {down }}\left|R_{m, t}{ }^{\text {down }}\right|+\gamma_{2}{ }^{\text {down }}\left(R_{m, t}{ }^{\text {down }}\right)^{2}+$ Et......eq (5)

Where CSADt is the average of the absolute value deviation of each stock relative to the return of market portfolio in period $\mathrm{t}$, and $\mid \mathrm{Rm}$, tup $\mid(\mid \mathrm{Rm}$,tdown $\mid)$ is the absolute value of an equally weighted realized return of all available securities on day $t$ when the market is up (down). In addition, the CCK model facilitates the detection of herding over the entire distribution of market return with the following specification:
$\operatorname{CSAD}_{\mathrm{t}}=\alpha+\gamma_{1}\left|\mathrm{R}_{\mathrm{m}, \mathrm{t}}\right|+\gamma_{2} \mathrm{R}^{2}{ }_{\mathrm{m}, \mathrm{t}}+\varepsilon_{\mathrm{t}} \ldots \ldots \ldots \ldots . \mathrm{eq}(6)$

CSADt, is a measure of return dispersion, which is measured by the cross-sectional absolute deviation:

$\mathrm{CSADt}=\frac{1}{N} \sum_{i=1}^{N}|R i, t-R m, t|$

Thus, if herding exists, the coefficient $\gamma 2$ is expected to be negative and statistically significant.

However, in this study we prefers to use the term positive market return (RMp) instead of 'up market' and negative market return (RMn) instead of 'down market' for the seek of simplicity. The following model is developed by changing only up and down terms to positive and negative market return.

$\operatorname{CSAD}_{\mathrm{t}}^{\mathrm{p}}=\alpha+\gamma_{1}{ }^{\mathrm{p}}\left|\mathrm{RMp}_{\mathrm{t}}\right|+\gamma_{2} \mathrm{p}^{\mathrm{p}}\left(\mathrm{RMp}_{\mathrm{t}}\right)^{2}+\varepsilon_{\mathrm{t}} \ldots \ldots$ eq $(8)$

$\operatorname{CSAD}_{t}{ }^{n}=\alpha+\gamma_{1}{ }^{n}\left|R_{n} n_{t}\right|+\gamma_{2}{ }^{n}\left(\operatorname{RMn}_{t}\right)^{2}+\varepsilon_{t} \ldots$. eq $(9)$

Where CSADt is the average of an absolute value deviation of each stock relative to the return of the market portfolio in period $t$, and $|R m, t p|(|R m, t n|)$ is the absolute value of realized return of all available securities on day $t$ when the market return is positive (negative). In addition, the CCK model facilitates the detection of herding over the entire distribution of market return with the following specification: $\mathrm{CSAD}_{\mathrm{t}}=\alpha+\gamma_{1}\left|\mathrm{RM}_{\mathrm{t}}\right|+\gamma_{2} \mathrm{RM}^{2}{ }_{\mathrm{t}}+\varepsilon_{\mathrm{t}} \ldots \ldots \ldots . . \mathrm{eq}(10)$

\section{EMPIRICAL ANALYSIS}

The empirical analysis section has two parts. The first section shows the regression results using BIST 30 index and the second section presents the empirical findings for the sub periods.

\section{A. Test of herding using BIST 30 index}

As a starting point, we run a test for correlation using daily data among the three big indexes in Istanbul stock exchange and the result is presented in table 1 below. Accordingly, there is a strong correlation among the three indexes. As it can be seen from table 1, the correlation among these indexes is above $99 \%$ and it is possible to reach to a similar finding by using one of the three index as a market indicator. Thus, in this section BIST 30 index is used to test the existence of herding in Istanbul stock exchange by using the two methods.

TABLE I: THE CORRELATION BETWEEN BIST 30, BIST 50 AND BIST 100 INDEX

\begin{tabular}{|l|l|l|l|}
\hline \multicolumn{2}{|l|}{ Covariance Analysis: Ordinary } & \\
\hline Observations & RM30 & RM50 & RM100 \\
\hline RM30 & 1.000000 & & \\
\hline RM50 & 0.998520 & 1.000000 & \\
\hline RM100 & 0.996825 & 0.999230 & 1.000000 \\
\hline
\end{tabular}

Source: Eviews

\section{B. Regression results using modified CSSD model}

Table 2 below shows the regression result using the modified CSSD model. According to the modified CSSD model regression results, the model has a statistically significant F-statistics for the three data types. According to table 2 results, the coefficient of RMp (a time when the market return is positive) is positive and statistically significant at $1 \%$ and $5 \%$ level of significance. This result shows that the value of CSSD increases when the market raises and it indicates that herding is not found when the market raises. On the other hand, the coefficient of RMn 
(when the market return is negative) is both negative and statistically significant at $1 \%$ and $5 \%$ level of significance in the daily and weekly data. However, the monthly data has a negative but statistically insignificant coefficient. Thus, the negative and statistically significant finding in the daily and weekly data indicates the existence of herding when the market falls. This finding indicate that investors price stocks differently when the market rises and falls. Accordingly, investors behave rationally when the market rises but they herd towards the market consensus when the market falls and behave irrationally by imitating the market consensus.

TABLE II: SUMMARY OF THE REGRESSION RESULT FOR MODIFIED CSSD MODEL

\begin{tabular}{|l|l|l|l|l|}
\hline $\begin{array}{l}\text { Freque } \\
\text { ncy }\end{array}$ & $\beta^{\mathrm{n}}$ & $\beta^{\mathrm{p}}$ & $\begin{array}{l}\text { Prob(F- } \\
\text { statistics })\end{array}$ & $\mathrm{R}^{2}$ \\
\hline Daily & $\begin{array}{l}-0.269497 \\
\mathrm{p} \text {-value } \\
(0.0000)\end{array}$ & $\begin{array}{l}0.270595 \\
\mathrm{p} \text {-value } \\
(0.0000)\end{array}$ & 0.000000 & 0.274110 \\
\hline Weekly & -0.253879 & $\begin{array}{l}0.314860 \\
\mathrm{p} \text {-value } \\
(0.0000)\end{array}$ & 0.000000 & 0.101576 \\
& $\begin{array}{l}\text { p-value } \\
(0.0000)\end{array}$ & $\begin{array}{l}0.238876 \\
\text { p-value } \\
(0.0001)\end{array}$ & 0.000408 & 0.067305 \\
\hline $\begin{array}{l}\text { Monthl } \\
\text { y }\end{array}$ & $\begin{array}{l}\text { p-value } \\
(0.1199)\end{array}$ & & \\
\hline
\end{tabular}

Source: Eviews

\section{Regression results using CSAD model}

The following tables (table 3, 4 and 5) shows the regression results using the CSAD model. Table 3 below shows the regression results when the market return is positive and the F-statistics is statistically significant at $1 \%$ and $5 \%$ level for the three data types. Accordingly, the model is statistically significant and it has $0.687208,0.676186$ and $0.703698 \mathrm{R}^{2}$ values for daily, weekly and monthly data respectively. According to the CCK model, a negative and significant value for $\gamma_{2}$ indicates the existence of herding towards the market consensus. Thus, table 3 shows a negative and a statistically significant finding for $\gamma_{2}$ in the daily, weekly and monthly data. This finding shows that there is herding in Istanbul stock exchange when the market is raising. However, the coefficient of $\gamma_{2}$ significantly decreases from daily to weekly and to monthly data. The finding may imply that herding behavior is more prevalent in the daily data than weekly or monthly data.

TABLE III: REGRESSION RESULT USING CCK MODEL WHEN THE MARKET RETURN IS POSITIVE 1

\begin{tabular}{|l|l|l|l|l|}
\hline Frequency & $\gamma_{1}$ & $\gamma_{2}$ & $\begin{array}{l}\text { Prob(F- } \\
\text { statistics) }\end{array}$ & $\mathrm{R}^{2}$ \\
\hline Daily & $\begin{array}{l}0.831680 \\
\mathrm{p} \text {-value } \\
(0.0000)\end{array}$ & $\begin{array}{l}-4.061829 \\
\mathrm{p} \text {-value } \\
(0.0000)\end{array}$ & 0.000000 & 0.687208 \\
\hline Weekly & $\begin{array}{l}0.855888 \\
\mathrm{p} \text {-value } \\
(0.0000)\end{array}$ & $\begin{array}{l}-1.640772 \\
\mathrm{p}-\text {-value } \\
(0.0000)\end{array}$ & 0.000000 & 0.676186 \\
\hline Monthly & $\begin{array}{l}0.949966 \\
\mathrm{p} \text {-value } \\
(0.0000)\end{array}$ & $\begin{array}{l}-1.241469 \\
\mathrm{p} \text {-value } \\
(0.0000)\end{array}$ & 0.000000 & 0.703698 \\
& & \\
\hline
\end{tabular}

Source: Eviews

On the other hand, table 4 below presents the CCK model's regression results when the market return is negative. The regression model has a significant F-statistics that shows the validity of the model and the daily, weekly and monthly data has $0.633706,0.639239$ and $0.675546 \mathrm{R}^{2}$ values respectively. The coefficient of $\gamma_{2}$ is both negative and statistically significant at $1 \%$ and $5 \%$ level for the three data types. Therefore, the finding shows the existence of herding behavior in Istanbul stock exchange when the market falls. However, the coefficient of $\gamma_{2}$ is higher in the daily data than in the weekly and monthly data, which may indicate that herding behavior is more prevalent in the daily data than others. When we compare the coefficient of $\gamma_{2}$ when the market falls and raises, we can clearly observe that the coefficient of $\gamma_{2}$ is higher when the market falls than when it raises. This result indicates that herding is more prevalent when the market return is negative.

TABLE IV: REGRESSION RESULT USING CCK MODEL WHEN THE MARKET RETURN IS NEGATIVE ${ }^{2}$

\begin{tabular}{|c|c|c|c|c|}
\hline Frequency & $\gamma_{1}$ & $\gamma_{2}$ & $\begin{array}{l}\text { Prob(F- } \\
\text { statistics) }\end{array}$ & $\mathrm{R}^{2}$ \\
\hline Daily & $\begin{array}{l}0.859159 \\
\text { p-value } \\
(0.0000)\end{array}$ & $\begin{array}{l}-5.650999 \\
\text { p-value } \\
(0.0000)\end{array}$ & 0.000000 & 0.633706 \\
\hline Weekly & $\begin{array}{l}0.981745 \\
\text { p-value } \\
(0.0000)\end{array}$ & $\begin{array}{l}-3.781736 \\
\text { p-value } \\
(0.0000)\end{array}$ & 0.000000 & 0.639239 \\
\hline Monthly & $\begin{array}{l}1.281841 \\
\text { p-value } \\
(0.0000)\end{array}$ & $\begin{array}{l}-3.504502 \\
\text { p-value } \\
(0.0000)\end{array}$ & 0.000000 & 0.675546 \\
\hline
\end{tabular}

Source: Eviews

Finally, table 5 presents the regression results of CCK model for the entire market return and the model has a significant F-statistics. The model also has 0.444182, 0.443149 and $0.336290 \mathrm{R}^{2}$ values for the daily, weekly and monthly data respectively. According to the finding, there is only a negative and statistically significant coefficient for $\gamma_{2}$ value in the daily data. There is a positive and statistically significant value for $\gamma_{2}$ in the weekly data and there is a positive but insignificant value for $\gamma_{2}$ in monthly data. Thus, this finding shows that herding is found only in the daily data and there is no herding in the weekly data.

TABLE V: REGRESSION RESULT USING CCK MODEL FOR THE ENTIRE MARKET RETURN ${ }^{3}$

\begin{tabular}{|l|l|l|l|l|}
\hline Frequency & $\gamma_{1}$ & $\gamma_{2}$ & $\begin{array}{l}\text { Prob(F- } \\
\text { statistics })\end{array}$ & $\mathrm{R}^{2}$ \\
\hline Daily & $\begin{array}{l}0.320539 \\
\text { p-value } \\
(0.0000)\end{array}$ & $\begin{array}{l}-0.707183 \\
\text { p-value } \\
(0.0000)\end{array}$ & 0.000000 & 0.444182 \\
\hline Weekly & $\begin{array}{l}0.216983 \\
\text { p-value } \\
(0.0000)\end{array}$ & $\begin{array}{l}0.475743 \\
\text { p-value } \\
(0.0000)\end{array}$ & 0.000000 & 0.443149 \\
\hline Monthly & $\begin{array}{l}0.225482 \\
\text { p-value } \\
(0.0000)\end{array}$ & $\begin{array}{l}0.030811 \\
\text { p-value } \\
(0.8047)\end{array}$ & 0.000000 & 0.336290 \\
& \multicolumn{3}{|l}{} \\
\hline
\end{tabular}

Source: Eviews

Thus, from the above findings it is possible to conclude that herding behavior is more prevalent when the market return falls and from the three data types it is dominant in the daily data than others.

\section{Test of herding behavior in sub periods}

The empirical finding in the above sections shows that

\footnotetext{
${ }^{1} \operatorname{CSAD}_{\mathrm{t}}^{\mathrm{p}}=\alpha+\gamma_{1}{ }^{\mathrm{p}}\left|\mathrm{R}_{\mathrm{m}, \mathrm{t}}^{\mathrm{p}}\right|+\gamma_{2}{ }^{\mathrm{p}}\left(\mathrm{R}_{\mathrm{m}, \mathrm{t}^{\mathrm{p}}}\right)^{2}+\varepsilon_{\mathrm{t}}$

${ }^{2} \operatorname{CSAD}_{\mathrm{t}}{ }^{\mathrm{n}}=\alpha+\gamma_{1}{ }^{\mathrm{n}}\left|\mathrm{R}_{\mathrm{m}, \mathrm{t}}{ }^{\mathrm{n}}\right|+\gamma_{2}{ }^{\mathrm{n}}\left(\mathrm{R}_{\mathrm{m}, \mathrm{t}}{ }^{\mathrm{n}}\right)^{2}+\varepsilon$
}

${ }^{3} \mathrm{CSAD}_{\mathrm{t}}=\alpha+\gamma_{1}\left|\mathrm{R}_{\mathrm{m}, \mathrm{t}}\right|+\gamma_{2} \mathrm{R}_{\mathrm{m}, \mathrm{t}}^{2}+\varepsilon_{\mathrm{t}}$ 
herding behavior exists when the market falls and it also exists in the daily data throughout the study period. However, as figure one below shows there is a low and high level of market return volatility in the study periods and the above empirical findings did not show whether herding is symmetrical in low and high market volatility periods. Thus, in this section herding behavior is tested in low and high market volatility periods and the study period is divided in to four sub periods based on both BIST 100 index 21 day volatility level and BIST 100 index return data. The study period contains two highly volatile periods: from $01 / 01 / 2000$ to $11 / 03 / 2004$ and from $22 / 05 / 2006$ to $08 / 10 / 2013$; as well as it contains two low volatile periods: from $12 / 03 / 2004$ to $18 / 05 / 2006$ and from $09 / 10 / 2013$ to $31 / 12 / 2018$. This classification is clearly indicated in the following graph.

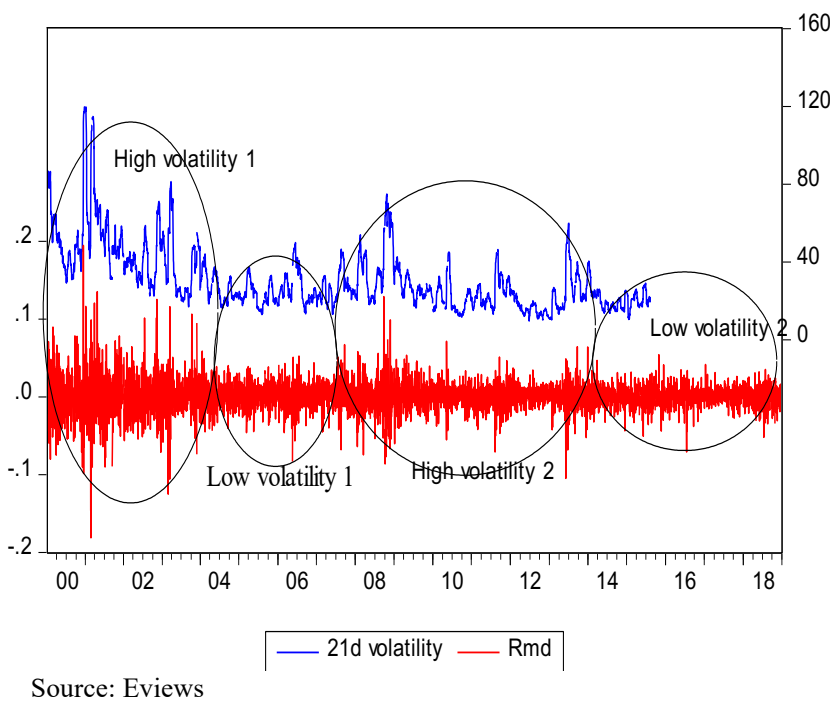

Fig. 1: Volatility level for the sub periods

Table 6 below presents the regression result using the modified CSSD model to study herding behavior in high and low volatile sub periods using the daily, weekly and monthly data. The regression result in the daily data for the two sub periods have a significant F-statistics and for the weekly and monthly data there is only a significant F-statistics for high volatile sub periods. Accordingly, the following interpretation focuses only for these periods. For the daily, weekly and monthly data, the coefficient of RMp is positive and statistically significant at $1 \%$ and $5 \%$ level and it indicates that there is no herding in Istanbul stock exchange for these sub periods. However, RMn has a negative and statistically significant coefficients that indicates the existence of herding in the specified periods (daily data as well as in the weekly data). When the market falls, even if there is a negative and statistically significant values for the daily data, we can conclude that the level of herding may be higher when the market volatility is high than when market volatility is low. Thus, this sub period finding is consistent with the above findings.
TABLE VI: SUMMARY OF THE REGRESSION RESULT FOR MODIFIED CSSD MODEL

\begin{tabular}{|c|c|c|c|c|c|}
\hline $\begin{array}{l}\text { Frequen } \\
\text { cy }\end{array}$ & $\begin{array}{l}\text { Level of } \\
\text { volatility }\end{array}$ & $\beta^{\mathrm{n}}$ & $\beta^{p}$ & $\begin{array}{l}\text { Prob(F- } \\
\text { statistics } \\
\text { ) }\end{array}$ & $\mathrm{R}^{2}$ \\
\hline \multirow[t]{2}{*}{ Daily } & $\begin{array}{l}\text { High } \\
\text { volatile } \\
\text { periods }\end{array}$ & $\begin{array}{l}-0.239096 \\
\text { p-value } \\
(0.0000)\end{array}$ & $\begin{array}{l}0.248160 \\
\text { p-value } \\
(0.0000)\end{array}$ & $\begin{array}{l}0.00000 \\
0\end{array}$ & $\begin{array}{l}0.259 \\
331\end{array}$ \\
\hline & $\begin{array}{l}\text { Low } \\
\text { volatile } \\
\text { periods }\end{array}$ & $\begin{array}{l}-0.201595 \\
\text { p-value } \\
(0.0000)\end{array}$ & $\begin{array}{l}0.173111 \\
\text { p-value } \\
(0.0000)\end{array}$ & $\begin{array}{l}0.00000 \\
0\end{array}$ & $\begin{array}{l}0.092 \\
585\end{array}$ \\
\hline \multirow[t]{2}{*}{ Weekly } & $\begin{array}{l}\text { High } \\
\text { volatile } \\
\text { periods }\end{array}$ & $\begin{array}{l}-0.223898 \\
\text { p-value } \\
(0.0000)\end{array}$ & $\begin{array}{l}0.327075 \\
\text { p-value } \\
(0.0000)\end{array}$ & $\begin{array}{l}0.00000 \\
0\end{array}$ & $\begin{array}{l}0.107 \\
668\end{array}$ \\
\hline & $\begin{array}{l}\text { Low } \\
\text { volatile } \\
\text { periods }\end{array}$ & $\begin{array}{l}-0.150194 \\
\text { p-value } \\
(0.0372)\end{array}$ & $\begin{array}{l}0.062421 \\
\text { p-value } \\
(0.4087)\end{array}$ & $\begin{array}{l}0.11359 \\
6\end{array}$ & $\begin{array}{l}0.011 \\
265\end{array}$ \\
\hline \multirow[t]{2}{*}{ Monthly } & $\begin{array}{l}\text { High } \\
\text { volatile } \\
\text { periods }\end{array}$ & $\begin{array}{l}-0.031814 \\
\text { p-value } \\
(0.7466)\end{array}$ & $\begin{array}{l}0.217884 \\
\text { p-value } \\
(0.0045)\end{array}$ & $\begin{array}{l}0.01187 \\
2\end{array}$ & $\begin{array}{l}0.063 \\
120\end{array}$ \\
\hline & $\begin{array}{l}\text { Low } \\
\text { volatile } \\
\text { periods }\end{array}$ & $\begin{array}{l}-0.226021 \\
\text { p-value } \\
(0.1591)\end{array}$ & $\begin{array}{l}0.259242 \\
\text { p-value } \\
(0.0554)\end{array}$ & $\begin{array}{l}0.14529 \\
2\end{array}$ & $\begin{array}{l}0.044 \\
374\end{array}$ \\
\hline
\end{tabular}

The CCK model regression result is presented in table 7 below when the market return is positive. The F-statistics result is statistically significant at $1 \%$ and $5 \%$ significance level that shows the validity of the model. The value of $\gamma_{2}$ is negative and statistically significant for all sub periods and it indicates the existence herding in Istanbul stock exchange for the period from 2000 to 2018 . Thus, this finding is consistent with the finding obtained in the above regression results. Even if herding is found throughout the study period, there is one interesting finding observed below. The finding shows that the coefficient of $\gamma_{2}$ is significantly higher in low volatile periods than high volatile periods. This finding is inconsistent with the theoretical explanation, herding is more prevail in crisis periods. The finding shows that herding is more prevalent in a low volatile periods and it happens during a stable market conditions.

TABLE VII: REGRESSION RESULT USING CCK MODEL WHEN THE MARKET RETURN IS POSITIVE ${ }^{4}$

\begin{tabular}{|c|c|c|c|c|c|}
\hline $\begin{array}{l}\text { Frequen } \\
\text { cy }\end{array}$ & $\begin{array}{l}\text { Level of } \\
\text { volatility }\end{array}$ & $\gamma_{1}$ & $\gamma_{2}$ & $\begin{array}{l}\text { Prob(F- } \\
\text { statistics) }\end{array}$ & $\mathrm{R}^{2}$ \\
\hline \multirow[t]{2}{*}{ Daily } & $\begin{array}{l}\text { High } \\
\text { volatile } \\
\text { periods }\end{array}$ & $\begin{array}{l}0.803904 \\
\text { p-value } \\
(0.0000)\end{array}$ & $\begin{array}{l}-3.976536 \\
\text { p-value } \\
(0.0000)\end{array}$ & 0.000000 & $\begin{array}{l}0.67134 \\
7\end{array}$ \\
\hline & $\begin{array}{l}\text { Low } \\
\text { volatile } \\
\text { periods }\end{array}$ & $\begin{array}{l}1.297987 \\
\text { p-value } \\
(0.0000)\end{array}$ & $\begin{array}{l}-21.54534 \\
\text { p-value } \\
(0.0000)\end{array}$ & 0.000000 & $\begin{array}{l}0.65688 \\
8\end{array}$ \\
\hline \multirow[t]{2}{*}{ Weekly } & $\begin{array}{l}\text { High } \\
\text { volatile } \\
\text { periods }\end{array}$ & $\begin{array}{l}0.881667 \\
\text { p-value } \\
(0.0000)\end{array}$ & $\begin{array}{l}-1.824053 \\
\text { p-value } \\
(0.0000)\end{array}$ & 0.000000 & $\begin{array}{l}0.69258 \\
1\end{array}$ \\
\hline & $\begin{array}{l}\text { Low } \\
\text { volatile } \\
\text { periods }\end{array}$ & $\begin{array}{l}1.777261 \\
\text { p-value } \\
(0.0000)\end{array}$ & $\begin{array}{l}-19.08217 \\
\text { p-value } \\
(0.0000)\end{array}$ & 0.000000 & $\begin{array}{l}0.67644 \\
6\end{array}$ \\
\hline \multirow[t]{2}{*}{ Monthly } & $\begin{array}{l}\text { High } \\
\text { volatile } \\
\text { periods }\end{array}$ & $\begin{array}{l}0.883873 \\
\text { p-value } \\
(0.0000)\end{array}$ & $\begin{array}{l}-1.119112 \\
\text { p-value } \\
(0.0000)\end{array}$ & 0.000000 & $\begin{array}{l}0.70188 \\
2\end{array}$ \\
\hline & $\begin{array}{l}\text { Low } \\
\text { volatile } \\
\text { periods }\end{array}$ & $\begin{array}{l}1.724847 \\
\text { p-value } \\
(0.0000)\end{array}$ & $\begin{array}{l}-7.302006 \\
\text { p-value } \\
(0.0000)\end{array}$ & 0.000000 & $\begin{array}{l}0.76858 \\
8\end{array}$ \\
\hline
\end{tabular}

Source: Eviews

Table 8 below presents the CCK model's regression results when the market return falls. The F-statistics for all sub periods is statistically significant at $1 \%$ and $5 \%$ level. According to the regression result, the coefficient of $\gamma_{2}$ is negative and statistically significant at $1 \%$ and $5 \%$ level for

${ }^{4} \operatorname{CSAD}_{\mathrm{t}}^{\mathrm{p}}=\alpha+\gamma_{1}{ }^{\mathrm{p}} \mid \mathrm{R}_{\mathrm{m}, \mathrm{t}} \mathrm{p}^{\mathrm{p}}+\gamma_{2}{ }^{\mathrm{p}}\left(\mathrm{R}_{\mathrm{m}, \mathrm{t}^{\mathrm{p}}}\right)^{2}+\varepsilon_{\mathrm{t}}$ 
all sub periods. Like table 7 regression finding, the coefficient of $\gamma_{2}$ is higher when the market volatility is low than higher volatility periods. Thus, this finding proofs that herding is more prevalent during low market volatility periods.

\section{TABLE VIII: REGRESSION RESULT USING CCK MODEL WHEN} THE MARKET RETURN IS NEGATIVE 5

\begin{tabular}{|c|c|c|c|c|c|}
\hline Frequency & $\begin{array}{l}\text { Level of } \\
\text { volatility }\end{array}$ & $\gamma_{1}$ & $\gamma_{2}$ & $\begin{array}{l}\text { Prob(F } \\
- \\
\text { statisti } \\
\text { cs) }\end{array}$ & $\mathrm{R}^{2}$ \\
\hline \multirow[t]{2}{*}{ Daily } & $\begin{array}{l}\text { High } \\
\text { volatile } \\
\text { periods }\end{array}$ & $\begin{array}{l}0.833794 \\
\text { p-value } \\
(0.0000)\end{array}$ & $\begin{array}{l}-5.355476 \\
\text { p-value } \\
(0.0000)\end{array}$ & $\begin{array}{l}0.0000 \\
00\end{array}$ & $\begin{array}{l}0.63630 \\
1\end{array}$ \\
\hline & $\begin{array}{l}\text { Low } \\
\text { volatile } \\
\text { periods }\end{array}$ & $\begin{array}{l}1.252074 \\
\text { p-value } \\
(0.0000)\end{array}$ & $\begin{array}{l}-19.31152 \\
\text { p-value } \\
(0.0000)\end{array}$ & $\begin{array}{l}0.0000 \\
00\end{array}$ & $\begin{array}{l}0.64877 \\
4\end{array}$ \\
\hline \multirow[t]{2}{*}{ Weekly } & $\begin{array}{l}\text { High } \\
\text { volatile } \\
\text { periods }\end{array}$ & $\begin{array}{l}0.972581 \\
\text { p-value } \\
(0.0000)\end{array}$ & $\begin{array}{l}-3.518902 \\
\text { p-value } \\
(0.0000)\end{array}$ & $\begin{array}{l}0.0000 \\
00\end{array}$ & $\begin{array}{l}0.64757 \\
2\end{array}$ \\
\hline & $\begin{array}{l}\text { Low } \\
\text { volatile } \\
\text { periods }\end{array}$ & $\begin{array}{l}1.418367 \\
\text { p-value } \\
(0.0000)\end{array}$ & $\begin{array}{l}-10.82453 \\
\text { p-value } \\
(0.0000)\end{array}$ & $\begin{array}{l}0.0000 \\
00\end{array}$ & $\begin{array}{l}0.62725 \\
0\end{array}$ \\
\hline \multirow[t]{2}{*}{ Monthly } & $\begin{array}{l}\text { High } \\
\text { volatile } \\
\text { periods }\end{array}$ & $\begin{array}{l}1.265563 \\
\text { p-value } \\
(0.0000)\end{array}$ & $\begin{array}{l}-3.437320 \\
\text { p-value } \\
(0.0000)\end{array}$ & $\begin{array}{l}0.0000 \\
00\end{array}$ & $\begin{array}{l}0.68377 \\
2\end{array}$ \\
\hline & $\begin{array}{l}\text { Low } \\
\text { volatile } \\
\text { periods }\end{array}$ & $\begin{array}{l}2.300919 \\
\text { p-value } \\
(0.0000)\end{array}$ & $\begin{array}{l}-14.71066 \\
\text { p-value } \\
(0.0000)\end{array}$ & $\begin{array}{l}0.0000 \\
00\end{array}$ & $\begin{array}{l}0.79072 \\
3\end{array}$ \\
\hline
\end{tabular}

Source: Eviews

Table 9 below presents the regression result for the entire market returns using the CCK model. Accordingly, the Fstatistics result is statistically significant for all sub periods except one sub period. There is only a significant coefficient for $\gamma_{2}$ value for daily data, and there is only a negative and statistically significant coefficient $\gamma_{2}$ for high volatile period. Thus, according to this finding there is herding in the daily data and in high volatile period. For the low volatile period and the daily data, there is no herding. In the weekly data and high volatile period, there is a positive and significant coefficient and it refers there is no herding at this market condition. In the case of monthly data there is no significant finding. In general, herding behavior is more prevalent in the daily data and during high market volatility periods.

TABLE IX: REGRESSION RESULT USING CCK MODEL FOR THE ENTIRE MARKET RETURN ${ }^{6}$

\begin{tabular}{|c|c|c|c|c|c|}
\hline $\begin{array}{l}\text { Frequenc } \\
\mathrm{y}\end{array}$ & $\begin{array}{l}\text { Level of } \\
\text { volatility }\end{array}$ & $\gamma_{1}$ & $\gamma_{2}$ & $\begin{array}{l}\text { Prob(F- } \\
\text { statistics) }\end{array}$ & $\mathrm{R}^{2}$ \\
\hline \multirow[t]{2}{*}{ Daily } & $\begin{array}{l}\text { High } \\
\text { volatile } \\
\text { periods }\end{array}$ & $\begin{array}{l}0.304315 \\
\text { p-value } \\
(0.0000)\end{array}$ & $\begin{array}{l}-0.832278 \\
\text { p-value } \\
(0.0000)\end{array}$ & 0.000000 & $\begin{array}{l}0.42319 \\
3\end{array}$ \\
\hline & $\begin{array}{l}\text { Low } \\
\text { volatile } \\
\text { periods }\end{array}$ & $\begin{array}{l}0.156848 \\
\text { p-value } \\
(0.0000)\end{array}$ & $\begin{array}{l}2.024242 \\
\text { p-value } \\
(0.0000)\end{array}$ & 0.000000 & $\begin{array}{l}0.29559 \\
3\end{array}$ \\
\hline \multirow[t]{2}{*}{ Weekly } & $\begin{array}{l}\text { High } \\
\text { volatile } \\
\text { periods }\end{array}$ & $\begin{array}{l}0.237455 \\
\text { p-value } \\
(0.0000)\end{array}$ & $\begin{array}{l}0.294830 \\
\text { p-value } \\
(0.0399)\end{array}$ & 0.000000 & $\begin{array}{l}0.45348 \\
9\end{array}$ \\
\hline & $\begin{array}{l}\text { Low } \\
\text { volatile } \\
\text { periods }\end{array}$ & $\begin{array}{l}0.190762 \\
\text { p-value } \\
(0.0003)\end{array}$ & $\begin{array}{l}-0.023045 \\
\text { p-value } \\
(0.9718)\end{array}$ & 0.000000 & $\begin{array}{l}0.17335 \\
8\end{array}$ \\
\hline Monthly & $\begin{array}{l}\text { High } \\
\text { volatile } \\
\text { periods }\end{array}$ & $\begin{array}{l}0.171770 \\
\text { p-value } \\
(0.0035)\end{array}$ & $\begin{array}{l}0.099385 \\
\text { p-value } \\
(0.5069)\end{array}$ & 0.000000 & $\begin{array}{l}0.31926 \\
0\end{array}$ \\
\hline
\end{tabular}

${ }^{5} \operatorname{CSAD}_{\mathrm{t}}^{\mathrm{p}}=\alpha+\gamma_{1}{ }^{\mathrm{p}}\left|\mathrm{R}_{\mathrm{m}, \mathrm{t}}{ }^{\mathrm{p}}\right|+\gamma_{2}{ }^{\mathrm{p}}\left(\mathrm{R}_{\mathrm{m}, \mathrm{t}}{ }^{\mathrm{p}}\right)^{2}+\varepsilon_{\mathrm{t}}$

\begin{tabular}{|l|l|l|l|l|l|}
\hline & Low & $\begin{array}{l}0.243848 \\
\text { volatile }\end{array}$ & $\begin{array}{l}-0.061298 \\
\text { p-value } \\
\text { periods }\end{array}$ & $\begin{array}{l}\text { p-value } \\
(0.9737)\end{array}$ & \\
\hline
\end{tabular}

Source: Eviews

\section{E. Comparison of the empirical findings}

The theoretical model of herding behavior predict that herding may be stronger during periods of high market stress period because investors herd for the seek of comfort that comes from market consensus. In addition, obtaining additional reliable information is limited as well as costly, then the better solution is to imitate the decision of other(s) [9]. According to our empirical finding and according to the modified CSSD model, herding is found in the daily data when the market is both in high and low level of volatility. In the weekly data, herding is found only when the market is in high level of volatility. Thus, according to the modified CSSD model, in terms of magnitude herding is more prevalent when the market is in high level of volatility. According to the CSAD model, when positive and negative return data is regressed separately, herding behavior is observed whether the market is in high or low volatile periods. Thus, according to this finding, the magnitude of herding is high when the market volatility is low. But as it can be seen in table 9, when we regressed the entire market return data, herding behavior is only found in the daily data and during high market volatile period. These two models' findings have many theoretical as well as empirical findings that support both findings.

The finding of the modified CSSD model is consistent with the theoretical explanation that herding is more prevalent during crisis periods because getting reliable information is tough during these periods as well as the information is so costly. As a result, imitating the crowd become the only available option for investors. On the other hand, the finding of the CSAD model can be explained by the fact that investors are more willing to imitate other investors' decision during periods where the market is stable and when investors are more comfortable to predict the direction of the market.

We hope that the theory of investors' attention towards specific or group of securities can explain the above finding very well. In the following paragraphs we give emphasis on explaining about investors' attention during investment process.

Reference [38] tested the proposition that says "individual investors are more likely to buy than sell stocks that catch their attention', The rationale for testing this proposition is that attention affects buying more than selling. In other words, each investor does not buy every single stock that grabs his attention rather individual investors are more likely to buy special attention-grabbing stocks than to sell them. The empirical finding of [38] strongly supports the specified proposition. According to [38], individual investors are net buyers of attention grabbing stocks like stocks in the news, stocks experiencing high abnormal trading volume and stocks with extreme one-day returns. Attention driven buying occurs due to the difficulty of searching from many stocks they can potentially buy. However, individual investors do not face the same search problem when selling because they tend to sell only stocks they already own. Accordingly, [38] hypothesize

${ }^{6} \mathrm{CSAD}_{\mathrm{t}}=\alpha+\gamma_{1}\left|\mathrm{R}_{\mathrm{m}, \mathrm{t}}\right|+\gamma_{2} \mathrm{R}_{\mathrm{m}, \mathrm{t}}^{2}+\varepsilon_{\mathrm{t}}$ 
that many investors consider buying stocks only that have first caught their attention. In the existence of many alternatives, options that attract attention are more likely to be considered and more likely to be chosen while options that do not attract attention are often ignored. An attentiongrabbing event has a chance to be reported in the news and an event that attracts the attention of many investors is newsworthy. Thus, important news about a firm often results in significant positive or negative returns. Even when there is a big price move, it is likely that whatever caused the move can caught investors' attention. In the case if price is responding to private information, the significant returns will often attract attention [38].

Many theoretical models of financial markets consider buying and selling as two sides of the same coin. But for actual investors, the decisions to buy and to sell are fundamentally different. When buying a stock, investors are faced with a formidable search problem. Like individual investors, institutional investors also face search problems. However, institutional investors devote more time to search for stocks to buy and sell than do most individuals. Institutional investors use computers to narrow their search and may limit their search to stocks in a particular sector or fulfil specific criteria such as low price to earnings ratio [38].

Due to the existence of many securities to be considered, investors face a formidable challenge when looking for a security to buy. Since there are limited resources to evaluate each security, investors are likely to consider purchasing securities to which their attention has been drawn. Investors may think about buying securities they have recently read about in the newspaper or heard about on the news. Those securities that have unusually well or poor performance are more likely to be discussed in the media, more likely to be considered by individual investors and more likely to be purchased. Accordingly, momentum investors may buy previous winners to which their attention has been directed and contrarian investors may buy previous losers to which their attention has been directed [39]. However, a fully rational investor will recognize the limitations of buying stock that predominantly catch their attention. They will realize that the information associated with attention grabbing event may not be relevant to future performance and that non attention grabbing stocks may present better purchase opportunities. An overconfident investor may overvalue the importance of events that catch their attention [38]. For most investors the decision to buy a security is quite different from the decision to sell. The formidable search problems for purchasing does not apply to sales [39].

According to [40] high investors' attention can exacerbate price overreaction in the up market. According to [41], even though standard asset pricing models assume that markets distill new information with high speed and they provide the best possible estimate of securities price, recent studies suggest that investor attention could play an important role in determining asset prices. According to this new view, important news or information is not reflected by prices until investors pay attention to it. Due to the existence of vast amount of information and the inevitability of limited attention, investors have to be selective in information processing to come up with investment decisions. Limited attention leads investors to allocate or process more market and sector level information than firm specific factors. In an extreme case, investor allocates all attention to market and sector information and ignores all the firm specific information.

So the herding behavior observed in the daily data and in high market volatility periods may be better explained by investors' asymmetrical attention and response to news.

\section{Conclusions}

So far we investigated the existence of herding towards the market consensus using stock return data and we tested the existence of herding behavior during high and low market volatility periods. In order to test herding the CSSD and CSAD models are used. According to the CSSD model, herding towards the market consensus only exists when the market falls. However, when the market rises there is no herding behavior. However, the CSAD model (the nonlinear model) presents the existence of herding when the market rises and falls, especially in the daily data. Even if the magnitude of herding decreases in the weekly and monthly data, there is a statistically significant finding which shows herding is available in the weekly and monthly data. In addition, the finding shows the level of herding is significantly higher when the market volatility level is higher.

Therefore, the existence of herding shows that investors are not valuing securities based on fundamentals rather the finding shows investors buy and sell securities based on crowd psychology. We can say that when the market falls and market volatility is high, stock prices are not traded based on their fundamental values. Thus, there is a deviation in the fundamental value of stocks when the market falls and when the market volatility is high. This finding indicates that traders are acting irrationally while pricing securities. This is because, they make a group decision rather than trading based on their own beliefs and analysis. Herding towards the market consensus also shows the inability of rational arbitrageurs to correct the irrational investors herding behaviour. Movements in investor sentiment are unpredictable and betting against mispricing create a risk for arbitrageur. Especially, in the short run, investor sentiment becomes extreme and prices move even further away from fundamental value [42].

In our finding we get a weak evidence of herding in the monthly return data. According to [43] longer horizon returns are closely related to macroeconomic variables. Thus, the above empirical finding is consistent with this finding. If stock prices are not valued based on their fundamentals, then market will deviate from its efficiency level. Thus, we can conclude that in the daily data markets are not efficient because stock prices are not evaluated based on their fundamentals.

Furthermore, our empirical finding shows that herding is not short phenomena as expected. Especially the nonlinear model shows that herding is observed in the daily, weekly and monthly data. Therefore, this shows that when news comes to the market investors formulate herding or noise after news, but when other news comes the previous herding disappears and a new herding is formulated, and so on. Thus, herding is a continuous phenomenon.

In addition our finding has an implication towards fundamental (intrinsic value) analysis of stock price 
valuation. According to our empirical result, stocks are not valued based on fundamentals in the daily data and during high market volatility periods. Thus, when the regression method (market model) is used to estimate systematic risk (beta) and expected return of a stock, the best return interval is to use the monthly data. This is because for the monthly data we did not found herd behavior. According to [44], the use of daily returns to estimate beta or expected return exposes the estimation process to a significant biases. Therefore, our finding is consistent with Damodaran's conclusion.

The previous literatures relate under reaction to conservatism behavior of an investor and overreaction to representativeness bias of an investor. However, these explanations did not explain well why investors overreact to one news and underreact to the other news. Therefore, there should be another explanation that may address this issue both correctly and clearly. We conclude that overreaction and underreaction behavior of investors may be better explained by negativity bias. Human beings give more emphasis as well as react more to negative news and events than positive news and events. Thus, investors overreact to negative news and underreact to positive news. In other words, investors' psychology and sentiment to positive and negative news is not symmetrical.

Lastly, capital asset pricing model and factor models (Fama French two, three and five factor model as well as the four factor model) assumes that investors pricing behavior is symmetrical whether the market return is positive or negative as well as whether the volatility of the market is high or low. However, our findings shows that investors' pricing behavior is not symmetrical when the market return is down and when it is up. The empirical results indicate that investors give more emphasis when the market is down and they behave similarly, than when the market return is up. Furthermore, it shows that investors pricing behavior is not symmetrical when the market is in high volatility and when it is in low volatility. Thus, this finding indicates some loophole towards the capital asset pricing model and factor models.

\section{REFERENCES}

[1] W. Christie and R. Huang, "Do Individual Returns Herd around the Market?," Financial Analysts Journal, pp. 31-37, 1995.

[2] E. Chang, J. Cheng and A. Khorara, "Examination of herd behavior in equity markets," Journal of Banking \& Finance, pp. 1651-1679, 2000.

[3] K. C. Gleason, I. Mathurb and M. A. Peterson, "Analysis of Intraday Herding Behavior among the Sector ETFs," Journal of Empirical Finance, p. 681-694, 2004.

[4] S. Hwanga and M. Salmon, "Market stress and herding," Journal of Empirical Finance, pp. 585-616, 2004.

[5] R. Demirer and A. M. Kutan, "Does herding behavior exist in Chinese stock markets?," Int. Fin. Markets, Inst. and Money , p. 123-142, 2006.

[6] E. Altay, "Sermaye piyasasında sürü davranıșı," BDDK bankacıllk \& finansal piyasalar, 2008.

[7] L. Tan, T. C. Chiang, J. R. Mason and E. Nelling, "Herding behavior in Chinese stock markets," Pacific-Basin Finance Journal, pp. 61-77, 2008.

[8] R. Demirer, A. M. Kutana and C.-D. Chen, "Do investors herd in emerging stock markets?," Journal of Economic Behavior and Organization, pp. 283-295, 2010.

[9] H.-M. Sun and J. Shyu, "Do Institutional Investors Herd in Emerging Markets?," Asian Journal of Finance \& Accounting, pp. 1-19, 2010.
[10] H. Doğukanlı and B. Ergün, "IMKB'DE SÜRÜ DAVRANISI," IŞletme Fakültesi Dergisi, pp. 227-242, 2011.

[11] A. Kapusuzoglu, "Herding in the Istanbul Stock Exchange," African Journal of Business Management, pp. 1210-11218, 2011.

[12] K. Kayalıdere, "Hisse Senedi Piyasasında Sürü Davranışı," İşletme Araştırmaları Dergisi, pp. 77-94, 2012.

[13] B. Ergün and H. Doğukanl, "BIST’te Sürü Davranış1," Uluslararası Sosyal Araştırmalar Dergisi, pp. 690-699, 2015.

[14] H. Doğukanlı and B. Ergün, "BIST’te Sürü Davranışı," Finans Politik \& Ekonomik Yorumlar, pp. 7-24, 2015.

[15] H. H. Özsu, "Empirical analysis of herd behavior," International Journal of Economic Sciences, pp. 27-52, 2015.

[16] M. Yasir, "Herding behavior in emerging stock markets," 2018. [Online].

[17] K. C. Gleason, C. I. Lee and I. Mathur, "Herding Behavior in European Futures Markets," Finance Letters, pp. 5-8, 2003.

[18] P. Holmes, V. Kallinterakis and M. P. L. Ferreira, "Herding in a concentrated market," European Financial Management, pp. 1-24, 2011.

[19] M. Song, D. Kim and C. Won, "Earnings Uncertainty and Analyst Forecast Herding," Asia-Pacific Journal of Financial Studies, pp. 545-574, 2009.

[20] J. Lakonishok, A. Shleifer and R. W. Vishny, "Impact of institutional trading on stock prices," Journal of Financial Economics, pp. 23-43, 1992.

[21] A. Devenow and I. Welch, "Rational herding in financial economics," European Economic Review , pp. 603-615, 1996.

[22] W. De Bondt and W. Forbes, "Herding in analyst earnings forecasts," European financial management, pp. 143-163, 1999.

[23] J. R. Nofsinger and R. W. Sias, "Herding \& feedback trading by institutional \& individual investors," The Journal of Finance, pp. 2263-2295, 1999.

[24] I. Welch, "Herding among security analysts," Journal of Financial Economics, pp. 369 - 396, 2000.

[25] S. Bikhchandani and S. Sharma, "Herd behavior in financial market," IMF Staff Papers, pp. 279-310, 2001.

[26] R. W. Sias, "Institutional Herding," The Review of Financial Studies, pp. 165-204, 2004.

[27] S. Spyrou, "Herding in financial markets," Review of Behavioral Finance, pp. 175-194, 2013.

[28] H. K. Baker and J. R. Nofsinger, Behavioral finance, wiley, 2010.

[29] L. F. Ackert and R. Deaves, Behavioral finance, Cengage Learning, 2010.

[30] A. Tversky and D. Kahneman, "Judgment under Uncertainty," Science, pp. 1124-1131, 1974.

[31] H. Schwartz, Behavioral finance: investors, corporations and markets, Wiley, 2010.

[32] P. Rozin and E. B. Royzman, "Negativity Bias, Negativity Dominance, and Contagion," Personality and social psychology review, pp. 296-320, 2001.

[33] S. Soroka and S. Mcadams, "News, politics and negativity," Political Communication, pp. 1-22, 2015.

[34] Baumeister, E. Bratslavsky, Finkenauer and K. Vohs, "Bad Is Stronger Than Good," Review of general psychology, pp. 323-370, 2001.

[35] D. Kahneman and A. Tversky, "Prospect Theory: An Analysis of Decision under Risk," conometrica, pp. 263-291, 1979.

[36] T. A. Ito, J. T. Larse, N. K. S. and J. T. Cacioppo, "Negative information weighs more," Journal of personality social psychology, 1998.

[37] J. Cacioppo, S. Crites, W. Gardner and G. Bernston, "Bioelectrical echoes from evaluative categorizations," Journal of Personality and Social Psychology, pp. 115-125, 1994.

[38] B. M. Barber and T. Odean, "All that glitters," The review of financial studies, pp. 785-818, 2008 .

[39] T. Odean, "Do investors trade too much?," The American economic review, pp. 1279-1298, 1999.

[40] K. Hou, L. Peng and W. Xiong, "A tale of two anomalies," 2009. [Online]. https://www.princeton.edu/ wxiong/papers/anomaly.pdf. 
[41] L. Peng and W. Xiong, "Investor attention, overconfidence and category learning," Journal of Financial Economics, pp. 563-602, 2006.

[42] N. Barbaris, A. Shleifer and R. Vishny, "A model of investor sentiment," Journal of financial economic, pp. 307-343, 1998.

[43] G. A. Karolyi and R. M. Stulz, "Why Do Markets Move Together?," The Journal of Finance, pp. 951-986, 1996.

[44] A. Damodaran, Applied corporate finance, John Wiley \& Sons, Inc., 2015. 